\title{
Związki między koncentracją, kumulacją i monopolizacją władzy. Analiza modelowa
}

\section{The Connections between Concentration, Cumulation and Monopolisation of Power. Model Analysis}

Stowa kluczowe: koncentracja, kumulacja, monopolizacja, władza, monokracja

Keywords: concentration, cumulation, monopolisation, power, monocracy

Abstrakt: Koncentracja władzy w jednym ośrodku decyzyjnym państwa (lub: partii, kościoła, ruchu społecznego) umożliwia kumulację władzy, tzn. zespolenie w jednym typie instytucji kilku rodzajów i zakresów władzy (np. podporządkowanie władzy ustawodawczej i sqadowniczej woli i dyspozycjom władzy wykonawczej, przekształcenie parlamentu i sądów, prokuratury w narzędzia działania rządu, partii rządzacej). Trwatym skutkiem takich zmian może być z kolei monopolizacja władz -wyłączność uprawnień praktycznej zdolnoścido rzadzenia dla danej sity politycznej oraz proces uwiecznienia, reprodukcji takiego monopolu.

Abstract: The concentration of power in one state (or:party, church, social movement) decision-making centre makes it possible to cumulate power. One kind of institution join the several types and areas of power (e.g. subordination of the legislative and judicial authorities to the will and disposition of the executive, conversion of parliament and orchards, public prosecutor's office into tools of government, governing party). The permanent effect of such changes may be the monopolisation of the authorities - the exclusive practical ability to

* ORCID ID: https://orcid.org/0000-0002-6778-6787, profesor nauk humanistycznych, kierownik Katedry Teorii Polityki i Myśli Politycznej, Wydział Nauk Politycznych i Studiów Międzynarodowych, Uniwersytet Warszawski. Członek Komitetu Nauk Politycznych Polskiej Akademii Nauk. Specjalizacja badawcza: metodologiczne problemy nauki o polityce, teoria polityki, socjotechnika, wzorce kultury politycznej, mechanizmy partycypacji politycznej. 
govern for a given political force and the process of immortalisation, reproduction of such a monopoly.

\section{Wprowadzenie}

Potoczne wrażenia i opinie, że „ktoś ma wiele (zbyt wiele) władzy”, że ma więcej władzy faktycznej niż formalnie mu to przysługuje, że ktoś zawłaszcza władzę (państwo) itd. zwykle nie grzeszą precyzją. Są jednak wyrazem rzeczywistego, poważnego problemu praktycznego, teoretycznego i doktrynalnego zarazem; a ściślej mówiąc, co najmniej dwóch problemów. Po pierwsze, czy i jak można sprawować władzę, aby przyznać sobie i zagwarantować więcej władzy niż w punkcie wyjścia, a nawet niezbywalność władzy. Po drugie, jak rządzić, zarządzać, kierować, by sprawując władzę nad innymi samemu nie podlegać ich władzy (w postaci kontroli, ale i skutecznego nacisku, egzekwowania społecznych oczekiwań, wymagań, żądań). Jest to m.in. związane z problematyką nadużyć władzy (przesłanek i form nadużyć) ${ }^{1}$ oraz alienacji władzy.

Pomocna w rozważaniu tych problemów jest triada pojęć KONCENTRACJA - KUMULACJA - MONOPOLIZACJA WŁADZY.

Między koncentracją, kumulacjąi monopolizacją władzy-rozumianymi jako tendencje urzeczywistniające się w pewnym procesie lub jako stany rzeczy będące rezultatem takich procesów - zachodzą wielorakie związki.

Po pierwsze, jest to bodaj ewidentny - zarówno w procesach narastania, jak i w finalnych stanach rzeczy - związek korelacji (dodatniej). Co może polegać nie tylko na równoczesnym i niejako nierozłącznym (współ)występowaniu, ale również na wzajemnym sprzężeniu, niejako synchronizacji w procesach powstawania i utrwalania.

Po drugie, jest to związek genetyczny (co z czego wyrasta) - uwikłany, co prawda, w dylematy interpretacyjne w stylu ,co pierwsze: kura czy jajo". Związek polegający na tym, iż np. koncentracja władzy może pociągać za sobą kumulację władzy, ta zaś powodować monopolizację władzy. Nie jest to współzależność automatyczna ani „, fatalistycznie” nieuchronna i przesądzona, lecz raczej warunkowa, czyli uzależniona od wystąpienia określonego splotu czynników sprzyjających takiemu właśnie ukierunkowaniu sekwencji koncentracja - kumulacja - monopolizacja.

${ }^{1}$ Katalog nadużyć (i „niezdrowych” pokus) władzy, co prawda, głównie w optyce moralnopsychologicznej, zawiera praca: J. van Ginneken, The Psychology of Power. Tempations at the Top, New York 2015. 
W analizie tej genetycznej współzależności trzech rzeczonych zjawisk musi znaleźć subtelne zastosowanie rachunek warunków sprzyjających, koniecznych i wystarczających ${ }^{2}$. Analiza taka musi też być osadzona w konkretnych realiach historycznych, cywilizacyjnych i ustrojowych nie istnieje bowiem jeden uniwersalny algorytm takiej zależności; ani pod względem kolejności komponentów, ani też pod względem symetrii lub asymetrii sprzężeń zwrotnych we wzajemnych relacjach „w parach", jak i w oddziaływaniu między jedną tendencją/stanem rzeczy a związkiem wzajemnym dwóch pozostałych.

Po trzecie, jest to związek funkcjonalny, a więc oparty na istnieniu i zaspokajaniu określonego zapotrzebowania i na zasadzie: co czemu dobrze służy. Bo w rzeczy samej, koncentracja władzy w jednym ogniwie, ośrodku decyzyjnym lepiej służy monopolowi władzy niż dekoncentracja, gwarantowanie nieprzekraczalnych i z góry przesądzonych ram porządku politycznego przez funkcjonowanie i dopiero koordynowanie działania różnych rozproszonych, oddzielonych od siebie ogniw władzy. Kumulacja władzy - kiedy „w tych samych rękach” skupiona jest możliwość sychronizacji i komplementarności prawodawstwa, rządzenia i wymiaru sprawiedliwości, jeszcze lepiej w połączeniu z dominacją w świecie mediów i w instytucjach oświatowo-wychowawczych - jest poręczną formą monopolizacji władzy, podczas gdy trudno jest zrealizować taką ambicję w warunkach przestrzegania trójpodziału, a więc względnej autonomii i wzajemnego ograniczania, równoważenia się władz.

Po czwarte wreszcie, jest to związek strukturalny, polegający m.in. na tym, że w jednej strukturze instytucjonalnej łączy się różne, zazwyczaj realizowane osobno, funkcje i kompetencje, co właśnie pozwala harmonijnie przejść od koncentracji do kumulacji, a stąd do monopolizacji władzy. W dzisiejszych realiach polskich poglądowym tego przykładem jest status i sposób funkcjonowania Instytutu Pamięci Narodowej - jako narzędzia monopolu w „rządzie dusz”, niezawodnego dzięki zespoleniu funkcji i kompetencji edukacyjnych (wręcz indoktrynacyjnych), administracyjnych, śledczych - prokuratorskich, a nawet wyręczaniu sądowych. Ale ta instytucjonalna koncentracja i kumulacja uprawnień i faktycznych zdolności decyzyjno-egzekucyjnych znajduje wyraz również na poziomie jednostkowym - w postaci kumulacji ról/stanowisk; przykład tego to: łączenie mandatu posła ze stanowiskiem ministra, stanowiska w ministerstwie sprawiedliwości $\mathrm{z}$ funkcją prokuratora itp.

${ }^{2}$ Niezastąpiona jest w tym zadaniu typologia: J. Topolski, Metodologia historii, Warszawa 1973, rozdz. XXI - Procedura wyjaśniania w historii. 
Poniższe rozważania to przyczynek - głównie w postaci ustaleń interpretacyjnych oraz charakterystyki każdego z tych trzech członów - do potrzebnej pogłębionej analizy mechanizmów władzy opartej na zasadzie raczej samoregulacji i samoreprodukcji niż społecznej kreacji, kontroli, oceny, wymiany.

\section{Koncentracja władzy}

Pojęcie koncentracji władzy odnosi się nie tylko dorozwiązań strukturalno-funkcjonalnych - o znaczeniu wręcz ustrojowym - na poziomie państwa, ale również do sposobu kierowania innymi instytucjami politycznymi (jak partie, organizacje kombatanckie, młodzieżowe) i parapolitycznymi (jak kościoły) oraz do modelu zarządzania przedsiębiorstwem, korporacją.

Przez koncentrację władzy rozumie się zwykle formalne lub nieformalne, lecz faktycznie utrwalone w praktyce kierowania, zarządzania, rządzenia skupienie kompetencji władczych na danym szczeblu struktury państwowej (w procesie rządzenia państwem lub zarządzania określonym regionem lub sektorem administracji), na danym szczeblu organizacji politycznej (partii, stowarzyszenia) w jednym organie - kolegialnym lub nawet jednoosobowym ${ }^{3}$.

W tym drugim kontekście (koncentracja władzy w rękach jednej osoby - przywódcy, formalnego kierownika lub... osoby mającej status patrona, mocodawcy, koordynatora i selekcjonera zarazem, mimo formalnego niezajmowania stanowiska kierowniczego) m.in. mówi się o „wodzowskim” modelu partii politycznej. Określenie to - pierwotnie przypisane do partii i ruchów totalitarnych (faszystowskich ${ }^{4}$, stalinowskich, maoistowskich) - z czasem przestało dziwić i szokować w odniesieniu do partii politycznych powstałych i funkcjonujących w ustroju demokratycznym; co więcej, niekiedy nawet formalnie opierających swoje działanie na statutowych wzorcach i normach ,demokracji wewnątrzpartyjnej”.

Rozszyfrujmy dokładniej ten skrót myślowy „koncentracja”. Popierwsze, chodzi tu o „dośrodkowy” (niekiedy „kugórny”) schemat komunikacji wewnątrz danej struktury organizacyjnej, oparty na zasadzie ,wszystkie drogi prowadzą do Rzymu" (do organu lub stanowiska autorytatywnego

${ }^{3}$ Por. np. D. Janicka, Ustrój administracji w nowożytnej Europie, Toruń 2002.

${ }^{4}$ Por. A. Hertz, Szkice o totalitaryzmie, Warszawa 1995; rozdz. pt. Posłannictwo wodza; O władzy Stalina. 
i niezastąpionego w procesie rozstrzygania o ważności spraw i sposobach ich załatwiania). I w konsekwencji - o mechanizm uzależnienia pracy ciągłej, jak i konkretnych działań wszystkich ogniw danego szczebla lub wszystkich ogniw danej instytucji na każdym szczeblu od inicjatywy, dyrektyw, woli, przyzwolenia lub konkretnych zaleceń tego, kto ma i głos pierwszy, i ostatnie słowo. Zaleceń - to znaczy: czy to ściśle rozumianych nakazów, zakazów, czy wiążących jednak sugestii, zachęt, oznak przyzwolenia lub czytelnych przestróg. Zakłada to taką czy inną skalę i formę niesamodzielności tych wszystkich - organów, zespołów lub jednostek którzy w wykonywaniu zadań swojego szczeblai zakresu muszą „oglądać się" na wytyczne w punkcie wyjścia i na oceny, sygnały w toku działania ze strony nosiciela czy depozytariusza autorytetu, miarodajności opinii i decyzji.

Po drugie, chodzi tu zarówno o uprawnienia do podejmowania decyzji (określone normami kompetencyjnymi i procedurami, acz niekiedy tylko utrwalonymi zwyczajami), nadające danemu podmiotowi maksymalny zakres lub wyłączność „,sprawstwa kierowniczego"5, zapewniające mu status niezastąpionego koordynatora, regulatora działań ogniw podległych, alei „dyspozytora ruchu” dyscyplinującego wykonawców i podwykonawców. W dawnych wiekach i modelach monarchii jako jedynowładztwa wyrazem tego był m.in. dworski mechanizm łaski lub niełaski; dziś jest to np. odgórny, ,wodzowski” tryb obsadzania partyjnych list wyborczych w terenie zgodnie z wolą, preferencjami, kalkulacjami liderów i zarządów krajowych, a z pominięciem, zignorowaniem opinii lub nawet formalnych uprawnień ogniw i działaczy lokalnych.

Koncentracja władzy jest silnie skorelowana, ale jednak nietożsama, z jej centralizacją . Może więc polegać - w hierarchicznym, wieloinstancyjnym modelu zarządzania, administrowania - na skupieniu procesu decyzyjnego w ręku organów centralnych, przy sprowadzeniu instancji niższego szczebla do roli wykonawczej. Ale też koncentracja władzy może wiązać się $\mathrm{z}$ - najpierw praktycznym, potem usankcjonowanym formalnie - „spłaszczeniem” struktur zarządzania i kierowania, zmniejszeniem liczby ogniw pośrednich.

5 To sprawstwo kierownicze - w odróżnieniu od wykonawczego, pomocniczego itd. - jest atrybutemczyjejś władzy nad innymi w procesach kierowania, zarządzania, podejmowania decyzji. Zob. Cz. Znamierowski, Wina i odpowiedzialność, Warszawa 1957, część II.

${ }^{6}$ Por. na ten temat: L. Kolarska-Bobińska, Centralizacja i decentralizacja. Decyzje, władza, mity, Wrocław 1984. 
Nie należy jednak zapominać i o innym, sieciowym modelu organizacji wewnętrznej lub współdziałania podmiotów pod jakimś względem równorzędnych, ulegających jednak zewnętrznym ośrodkom koordynacji lub wręcz zaprogramowania albo faktycznej dominacji jednego z uczestników. Wtedy koncentracja władzy ma miejsce w... formalnie równoległym ogniwie koordynacyjnym lub też przejawia się w kluczowym i rozstrzygającym wpływie jednego z uczestników współdziałania formalnie opartego na schemacie transakcji, wymiany, kooperacji.

Wspólnym mianownikiem tych różnych sytuacji jest to, iż zawęża się krąg uczestników procesu decyzyjnego; w jakimkolwiek charakterze - inicjatorów, doradców, konsultantów, interesariuszy, kandydatów do podjęcia się rozstrzyganego zadania czy „misji”.

Pozostawmy na boku - najlepiej specjalistom z zakresu nauk o zarządzaniu, administracji - rozliczne dyskusje dotyczące wpływu koncentracji sprzężonej z centralizacją na efektywność kierowania, zarządzania, reprezentatywność i funkcjonalność społecznąitd. Do wiedzy szerszego kręgu obywateli, pracowników, wyborców docierają tylko elementy takich dyskusji, np. teza, iż nadmierna koncentracja władzy utrudnia zdobywanie informacji o sytuacji w terenie, pozbawia samodzielności i odpowiedzialności instytucje lub organy niższego szczebla, co w sytuacjach nagłych, kryzysowych przy utrudnionej komunikacji powoduje paraliż decyzyjny.

Uwagę politologa zwraca z pewnościąjedna kwestia o znaczeniu ustrojowym. Zakłada się na ogół, iż w przypadku nadmiernej i nieuregulowanej przejrzystymi normami koncentracji władzy w państwie, nadrzędna pozycja jednego organu władzy centralnej - jeśli niejest równoważona przez inne podmioty władzy i nie podlega ich kontroli - zaburza zasadę równowagi systemu politycznego i jest sprzeczna $z$ demokratyczną zasadą podziału władzy politycznej i państwowej.

\section{Możliwe formy koncentracji władzy}

Tak pojęta koncentracja władzy przejawia się w wielorakiej formie:

1) na zasadzie ścisłej hierarchizacji danej struktury instytucjonalnej czy organizacyjnej oraz centralizacji prerogatyw (wtedy ogniwa niższe w hierarchii są jedynie adresatem wymagań, nakazów i wykonawcą woli ośrodka kierowniczego, a w komunikacji zwrotnej jedynie autorem

7 Zob. A. Rothert, Emergencja rządzenia sieciowego, Warszawa 2008; zob. też A. Rothert, Wielopoziomowość władzy sieci, «Studia Politologiczne» 2011, vol. 20. 
„meldunków”); co jednak może być zakamuflowane drobiazgowością formalnych ,ponadczasowych" procedur i fasadowymi ozdobnikami w rodzaju rytualnych, a pozornych konsultacji, odbywających się w sytuacji, gdy „klamka już zapadła”, gdy decyzja jest przesądzona z góry;

2) na zasadzie takiego faktycznego spłaszczenia lub rozmycia (płynności) struktur władzy (rządzenia, zarządzania), aby Centrum kierowało „ręcznie” - wydając dyspozycje najbardziej szczegółowe dla konkretnych ogniw, ingerując $w$ ich działanie;

3) na takiej zasadzie, iż wprawdzie formalnie zachowane są uprawnienia ogniw podległych do działania samodzielnego we własnym zakresie na rzecz celów stałych (gdy normatywnie została określona i zachowana właściwość rzeczowa, instancyjna i terytorialna), jednak w praktyce ma miejsce skrępowanie tych ogniw nieformalnymi instrukcjami (nawet łamiącymi procedury i normy kompetencyjne), sygnalizowanymi oczekiwaniami, doraźnymi naciskami; w rezultacie wytresowania funkcjonariuszy i działaczy nauczonych oglądania się na wytyczne, w każdej sprawie upewniających się, czy odgadli oczekiwania ,góry”, unikających podejmowania decyzji na własne konto.

Koncentracja władzy co najmniej sprzyja jej kumulacji, a w niektórych okolicznościach ją powoduje.

$\mathrm{Na}$ czym polega kumulacja władzy?

\section{Trywialne pojęcie kumulacji}

Rzeczownik odczasownikowy kumulacja (odnoszący się do pewnych czynności lub do procesów niezależnych od umyślnego działania ludzkiego lub do stanów rzeczy będących rezultatem takich czynności albo procesów, tendencji) pochodzi od łacińskiego czasownika cumulare (gromadzić), związanego z kolei z prostym rzeczownikiem cumulus (kupa, obszerny lub pojemny zbiór czegoś, gromada). Kumulacja znaczy więc: nagromadzenie, skupienie czegoś w jednym miejscu czy momencie i stanie rzeczy.

W skojarzeniu najprostszym: sumowanie się czegoś, czyli przyrost, przybytek. Może to mieć znaczenie zarówno neutralne, pozytywne, jak i negatywne - np. gdy mowa jest o kumulacji dawek leku, szczepionki, ale równie dobrze trucizn $\mathrm{w}$ organizmie ${ }^{8}$.

${ }^{8}$ W. Kopaliński, Słownik wyrazów obcych i zwrotów obcojęzycznych z almanachem, Warszawa 1994, s. 285. 
Jednak oprócz tego sumarycznego, mechanicznego sensu słowu kumulacja może być przypisany sens integratywny - wtedy kładziemy nacisk na takie połączenie czegoś z czymś, takie skupienie się różnych komponentów w jakiejś postaci, taki splot czynników, że powstaje z tego nowa jakość, inna niż jakość poszczególnych komponentów albo nawet ich sumy 9 .

Tosumaryczne pojęcie kumulacji ma niewielką wartość poznawczą, gdy odniesiemy je do zakresu i siły władzy. Nie wykraczamy wówczas poza banalną konstatację, że ktoś „ma wiele władzy”, jak gdyby mowa była o zebraniu w jednej kolekcji wielu ciekawych eksponatów, może nawet rarytasów.

Natomiast integratywne pojęcie kumulacji pozwala zrozumieć i wyjaśnić, jak poważne są konsekwencje skupienia różnych rodzajów i narzędzi władzy z różnych sfer w uprawnieniach lub w każdym razie praktycznych możliwościach jednego podmiotu.

Kumulacja władzy to zjawisko syndromatyczne - gdy chodzi o charakterystykę struktury i funkcji - oraz dynamiczne, gdyż powstaje w pewnym procesie, a nie na zasadzie jednorazowego aktu konstytutywnego czy zdarzenia o przesądzonych długofalowych skutkach. Jeśli zaś rozpatrywać je w kategoriach stanu rzeczy - jako rezultat takiego procesu lub długofalowej strategii danego podmiotu - jest to splot kilku właściwości, które implikują efekt znacznie większy niż wynikający ze zsumowania atutów poszczególnych komponentów.

Nie dostrzega się tego w przypadku operowania trywialnym, sumarycznym rozumieniem samego słowa.

Najbardziej dosłowne i nieprzesadnie wyrafinowane rozumienie kumulacji (kumulacji jako takiej, czegokolwiek) podpowiada nam oczywiste skojarzenia: nagromadzenie czegoś, skupienie i przyrost (pewnych dóbr, zasobów, wartości symbolicznych, uprawnień lub obowiązków). Każdemu znana jest prosta ilustracja takiego sensu słowa: kumulacja w LOTTO, kiedy nieskonsumowana suma przeznaczona na główną wygraną w danym losowaniu zasila pulę do podziału w kolejnym.

W tym prostym sensie kumuluje władzę:

1) ten (ta osoba), kto skupia w swoich rękach role, funkcje, stanowiska, przypisane do nich prerogatywy (przechodząc od sumarycznej prze-

${ }^{9} \mathrm{~W}$ tym kontekście analizował Bronisław Malinowski ,integratywne nakazy kultury ludzkiej”. B. Malinowski, Kultura i jej przemiany, Warszawa 2000. Analiza strukturalna integratywności - w odróżnieniu od addytywności (integracji sumarycznej, mechanicznej) zawarta jest w monografii: M. Karwat, Podmiotowość polityczna. Humanistyczna interpretacja polityki w marksizmie, Warszawa 1980, część druga. 
wagi uprawnień i faktycznych możliwości do marginalizacji lububezwłasnowolnienia potencjalnych zmienników i opornych) - to wymiar personalny;

2) ten podmiot grupowy (ruch polityczny, partia, elita lub np. junta wojskowa), która podporządkowuje swojej woli (a gwarantuje to decydowanie o rozdziale zasobów i obsada kadrowa) kluczowe instytucje publiczne, organy i agendy państwa, służby państwowe - to wymiar instytucjonalny,

Ale w tym integratywnym ujęciu „dodanie” jakiegoś komponentu czy zasobu władzy do dotychczasowego powoduje zmianę zakresu i siły władzy, znacznie większą niż wynikałoby to ze skali „dodania”.

Porównajmy to np. ze sferą operacji giełdowych czy stosunków zarządzania przedsiębiorstwem: przyrost ,pakietu kontrolnego" akcji z 5\% lub $10 \%$ do $25 \%-30 \%$ to coś więcejniż ,poszerzenie” udziałów, to możliwość dysponowania danym kapitałem niemal na takiej zasadzie, jak gdyby było się formalnie jedynym właścicielem, jeśli pozostali udziałowcy dysponują - każdy z nich - tylko kilkoma procentami akcji, nie są zaś zdolni do współdziałania i wspólnego przeciwdziałania ze względu na zasadniczą rozbieżność swoich interesów i uzależnienie właśnie od partnera dominującego.

\section{Ścisła kumulacja władzy - ,ciąg technologiczny” i „obieg zamknięty”}

Dalej posunięta jest taka kumulacja władzy, która polega na tym, że poszczególne rodzaje władzy (wyodrębniane w klasycznym trójpodziale, ale dorzućmy do tego jeszcze „czwartą władzę” mediów, o ile przynajmniej część z nich ma status względnie niezależnych uczestników gry politycznej) nie pozostają już $\mathrm{z}$ osobna $\mathrm{w}$ rękach różnych sił politycznych i nie funkcjonują już zgodnie $\mathrm{z}$ własnymi regułami i zadaniami, lecz tworzą swoisty ,ciąg technologiczny" w procesie realizacji woli jednego podmiotu, który posiada władzę pełną (pod każdym względem, w każdym wymiarze), a nawet „wszechwładzę” (władzę nad każdym zakresem i poziomem życia społecznego).

Zwykle odpowiada temu wyraźna konsekwencja tego stanu rzeczy dla samych obywateli - w postaci sui generis „obiegu zamkniętego"10.

10 Obrazową, choć stereotypową ilustracją takiego mechanizmu, jest polski film fabularny „Układ zamknięty”. 
Na czym polega taki obieg zamknięty w „obsłudze” obywateli? Zarówno obywatel politycznie zaangażowany przeciw rządzącym lub w każdym razie aspirujący do niezależności, jak i obywatel apolityczny, którego interesy i prawa mogłyby zostać naruszone arbitralnym działaniem rządzących, zostaje pozbawiony możliwości efektywnego znalezienia alternatywy dla decyzji i działań zagrażających mu (np. w postaci procedur sądowych w niezależnym sądownictwie, instancji odwoławczych czy administracyjnych procedur skarg, zażaleń). Do kogokolwiek się odwoła - w sprzeciwie wobec naruszenia swoich praw i interesów lub profilaktycznie w obawie przed taką zmianą (np. w projektach ustawodawczych, w planowanych rozporządzeniach wykonawczych do ustaw, ale i w pewnych wymownych nominacjach kadrowych), efekt jest taki, jak gdyby zwracał się do samego inicjatora, sprawcy zagrożeń, choć formalnie kieruje swój głos do innego organu (np. gdy zaskarża decyzje prokuratury do sądu, który ma tego samego mocodawcę co prokuratura albo, gdy zgłoszenie do prokuratury doniesienia o podejrzeniu popełnienia przestępstwa dotyczy... prokuratora generalnego, czyli zwierzchnika tej prokuratury). Właśnie taki mechanizm jest przedmiotem kontrowersji, walki politycznej i propagandowej w toku reform ustrojowych towarzyszących „Dobrej Zmianie”.

\section{Arytmetyka kumulacji władzy}

Głębszą istotę zjawiska, które można określić jako kumulację władzy dobrze oddają intuicje matematyczne, tzn. porównanie(oczywiście w rozsądnych granicach analogii) ,efektu kumulacji” do wyniku takich działań jak potęgowanie, postęp geometryczny, postęp wykładniczy, kombinatoryka.

W każdym przypadku mamy do czynienia z zależnością podobną, choć zróżnicowaną we współczynnikach ilościowych. Mianowicie: splot dwóch wielkości daje wielkość (ilość i jakość) większą (bogatszą) niż arytmetyczna suma tych wielkości wyjściowych.

Zależność tego typu jest zresztą widoczna, gdy weźmiemy pod uwagę - na płaszczyźnie ustaleń socjologii - jakościową różnicę między grupami społecznymi o niedużej liczebności a grupami czy wspólnotami, społecznościami o dużej liczebności; różnicę skorelowaną z czynnikiem skupienia lub rozproszenia terytorialnego oraz kontaktowym i spersonalizowanym a zapośredniczonym i bezosobowym, anonimowym charakte- 
rem więzi ${ }^{11}$. Wzrost liczebności grupy (wspólnoty) jest skorelowany ze wzrostem złożoności jej struktury ${ }^{12}$. W tej socjologicznej regule potwierdza się dialektyczna prawidłowość, że narastanie zmian ilościowych skutkuje w pewnym momencie ,przekroczenia progu” zmianą jakości zjawiska ${ }^{13}$.

W oddziaływaniach społecznych między dwoma elementami (np. jednostkami lub grupami) w punkcie wyjścia, na pierwszy rzut oka, zachodzą tylko dwie relacje (wpływ podmiotu A na podmiot B i wpływ odwrotny). Ale nawet abstrahując od obecności i oddziaływania w ich otoczeniu jeszcze innego podmiotu lub kilku innych podmiotów, od uwikłania obydwu stron w określone więzi w ramach wspólnego środowiska, trudno następnie nie zauważyć, iż obie te relacje lub ich bilans pociągają za sobą np. związek wzajemnego uzależnienia lub np. jednostronnej przewagi (po jednej stronie) i również jednostronnej (zupełnej lub per saldo, w większym stopniu) podatności na nacisk po drugiej stronie.

Już uwzględnienie relacji (sprzężeń) zwrotnych zmienia bilans powiązania dwóch podmiotów, co jeszcze większe ma znaczenie, jeśli jest to bilans asymetryczny (podmiot A wpływa na podmiot B w większym zakresie, z większą intensywnością i niezawodnością niż samulega oddziaływaniom podmiotu B).

Jeśli współzależność między tymi dwoma podmiotami zachodzi ze względu na ich powiązanie z trzecim podmiotem, to rachunek relacji już „skokowo" się komplikuje.

Między trzema takimi elementami społecznymi zachodzi już co najmniej 12 możliwych relacji, jeśli weźmiemy pod uwagę nie tylko jednostronne relacje statyczne w dwóch kierunkach (od A do B i odwrotnie), a z pominięciem relacji zwrotnych i reakcji wtórnych tworzących nawet pewną spiralę zależności i oddziaływań, ale również relacje (także zachodzące w obydwu kierunkach) między więzami podmiotów A i B a podmiotem $\mathrm{C}$, między więzami podmiotów $\mathrm{A}$ i $\mathrm{C}$ a podmiotem $\mathrm{B}$, między więzami podmiotów B i C a podmiotem A. Każda z takich relacji oznacza możliwość praktycznego oddziaływania-wywierania wpływu, sprawowania i egzekwowania władzy. A przecież możliwa jest jeszcze

\footnotetext{
${ }^{11}$ Por. na ten temat analizę zasady emergencji w pracy: J. Szmatka, Jednostka i społeczeństwo. O zależności zjawisk indywidualnych od społecznych, Warszawa 1980.

12 Tu kłania się klasyka: G. Simmel, Socjologia, Warszawa 1975.

13 Interpretacja ontologicznego i metodologicznego sensu tej zapoznawanej, lekceważonej lub wulgarnie dziś rozumianej zasady nie zestarzała się w podręczniku: A. G. Spirkin, Zarys filozofii marksistowskiej, Warszawa 1969, s. 170-178.
} 
swoista metarelacja - sterowanie tą kombinacją relacji przez określony podmiot zewnętrzny lub wyodrębniony w ramach wspólnego ,układu” (w tym wypadku: podmiot władzy).

Jak to się ma do efektu kumulacji władzy?

Zilustrujmy to bardziej konkretnym przykładem: jeśli obóz rządzący ma nie tylko kontrolę, ale i wręcz możliwość „ręcznego kierowania” (w sposób spójny, konsekwentny) takim ciągiem „obsługi” obywatela lub grupy społecznej, jak: policja - prokuratura - sąd powszechny Sąd Najwyższy - Trybunał Konstytucyjny, to efektywność, niezawodność funkcjonowania takiego ciągu (zgodnie z wolą polityczną monopolisty) zapewniona jest właśnie przez to, że wszystkie ogniwa tego ciągu poddane są koordynacji właściwego ośrodka dyspozycji politycznej, zaś zich wzajemnych relacji usunięte zostają przesłanki utrudnień, barier dla realizacji apriorycznej woli rządzących. Bowiem każde ogniwo w tym ciągu robi „to, co do niego należy” nie z punktu widzenia własnych, autonomicznych reguł (założeń normatywnych i procedur), lecz z punktu widzenia wspólnego ,zamówienia politycznego”, a nawet wyraźnych politycznych dyspozycji.

Jest to przykład bardzo swoistego efektu synergii ${ }^{14}$.

\section{Monopol i monopol władzy}

I tu nie od rzeczy będzie zacząć od etymologii.

Samo słowo monopol-od dawna zakorzenione nie tylko w języku specjalistycznym ekonomii, prawa, nauki o polityce czy w języku publicystyki społeczno-politycznej, ale i w mowie potocznej-pochodzi zjęzyka greckiego. Jest to zrost dwóch członów: przymiotnika monos (sam, pojedynczy; jedyny) oraz przetworzonego czasownika polein - sprzedawać ${ }^{15}$. I rzeczywiście, w pierwotnej adaptacji na użytek gospodarki towarowopieniężnej termin monopol oznaczał wyłączne prawo do produkcji albo handlu w jakiejś dziedzinie, przysługujące osobie, grupie albo państwu (por. monopol spirytusowy, tytoniowy). Precyzyjne zastosowanie analityczne znalazł ten termin w odniesieniu do procesu przekształcania kapitalistycznej gospodarki wolnokonkurencyjnej w mechanizm monopolu właśnie, duopolu lub oligopolu.

14 Zob. systematyczne omówienie mechanizmu synergii: J. Hubert, Społeczeństwo synergetyczne, Kraków 2000.

15 W. Kopaliński, Słownik wyrazów obcych..., s. 338. 
Nie nazwiemy dziś monopolem copyrightu, ale zastrzeżenie praw autorskich i wydawniczych ma pokrewny kontekst jak ten pierwotny. $\mathrm{Z}$ czasem rozciągnięto zastosowanie tego terminu na stosunki ideologiczne i religijne (przykład: wyłączność instytucji kościelnych na prawdę), aż w końcu i na kwestię zakresu władzy w państwie - w tym kontekście monopol władzy zaczął oznaczać nieistnienie lub raczej zlikwidowanie alternatywy dla rządów określonej siły politycznej.

Gdy mowa o politycznym kontekście takiej „,wyłączności”, to w przekładzie na język polski ten grecki zrost wyrazów może mieć odpowiednik w słowie jedynowładztwo, ale przy określonych założeniach i zastrzeżeniach. Mianowicie: akcent kładziemy wtedy na jedyność, a więc wyłączność danej roli (w tym wypadku - właśnie decydowania o zachowaniach, sytuacji i losach innych ludzi, całych zbiorowości). Wyłączność jako fakt (gdy rzeczywiście nikt inny nie wywiera takiego wpływu, który jest aż władzą, bo polega na efektywnej zdolności narzucenia i wyegzekwowania woli), ale też jako uprawnienie (przesądzające o powtórzeniu i utrwaleniu takiej wyłączności w kierowaniu, rządzeniu innymi, w zarządzaniu określonymi strukturami); jako prerogatywa i wręcz przywilej.

Może to mieć wymowę powściągliwą, minimalistyczną (tylko ja - podmiot jednostkowy lub grupowy - jestem w stanie rządzić) lub maksymalistyczną i roszczeniową (tylko ja mam lub w każdym razie sam przyznaję, przypisuję sobie prawo do tego). Może to mieć wymowę profilaktyczną: Ja (resp. My) nikomu innemu na to nie pozwolę, nikogo do takiej roli nie dopuszczę. Może też to znaczyć: nikt nie jest w stanie w tym mnie zastąpić. Topołączenie roszczenia z mistyfikacją ideologiczną: przedstawianie, racjonalizowanie swojej roli - przywileju wyłączności - jako oczywistej i obiek-

tywnej konieczności; np. po hasłem: w interesiei w służbie zbiorowości muszę to wziąć na siebie i nie dopuścić podmiotów niepowołanych, uzurpatorów, potencjalnych szkodników itp., aby dobro wspólnoty nie ucierpiało.

$\mathrm{Z}$ tym zwykle bywa stowarzyszone trywialne i przeniknięte demoralizacją uznanie wyłączności w sprawowaniu władzy za prestiżowy przywilej (np. dla ,jedynie godnych”, dla ,najlepszych”, „,niezastąpionych”), za zasłużoną nagrodę za domniemane zasługi (np. ocalenie narodowe, wyprowadzenie kraju ze stanu katastrofy), albo wręcz za zdobycz strzeżoną walecznie i zazdrośnie, bo zaspokajającą własną potrzebę bycia ważnym, „używania”, komfortu, ewentualnie rewanżu za wcześniejsze upokorzenia, cierpienia, krzywdy (jak u niektórych dysydentów czy rewolucjonistów przeobrażających się - przy władzy - w autokratów i mścicieli). W najbardziej wulgarnym wydaniu oznacza to dewizę ,ta władza nam się po prostu należy”. 


\section{Monopol spersonalizowany - jedynowładztwo}

Jednak wyraz jedynowładztwo w terminologii polskiej mniej kojarzy się (jako synonim) z grupowym (klasowym, partyjnym, kościelnym czy koteryjnym) monopolem władzy, a bardziej z przypadkami ,ujednostkowienia" władzy, a więc skupienia całej i wyłącznej lub w każdym razie kluczowej władzy w osobie określonego człowieka w formalnej lub nieformalnej roli kierowniczej, przywódczej (tyran, despota, władca absolutny w czasach nowożytnych w Europie; Naczelnik-Komendant, dyktator - dyktator powstania; duce, führer; poseł Kaczyński „bez żadnego trybu").

Personifikacja władzy (postrzeganie i przedstawianie jej w kategoriach sprawczej, kreacyjnej roli jednostek przywódczych - np. monarchów, wodzów armii, ojców założycieli itp. ${ }^{16}$ ) oraz personalizacja władzy (konstytuowanie stosunku władzy przez przypisanie jednoosobowemu organowi kierowniczemu kluczowych prerogatyw, czyniących go jedynym źródłem woli politycznej i niezastąpionym gwarantem trwałości porządku politycznego) ${ }^{17}$ nie powinna jednak przesłaniać - przytomnym badaczom - faktu, iż to nie jednostka wyróżniona, uzbrojona - jak w ,samodierżawiu"18 - w moc skutecznego narzucania i egzekwowania dowolnych swoich zamiarów, planów, postanowień itd. jest źródłem i nosicielem stosunku władzy (władzy tak, ,nieograniczonej”), lecz, że jest ona tylko uosobieniem i kluczowym ogniwem mechanizmu społecznego.

W szczególności mitycznym wyobrażeniem jest stereotyp władcy, dyktatora, despoty, wodza jako osoby, która po prostu sama siebie wykreowała w roli przywódczej i władczej, sama wyznacza i przekracza granice swojej władzy, sama sobie wystarcza do obsługi i utrwalenia własnego panowania oraz do wypracowania strategii politycznej. Osoby, której nikt nie jest w stanie zastąpić (pod groźbą rozpadu danego reżymu), której nikt nie śmie ani praktycznie nie jest w stanie odmówić, a która

\footnotetext{
${ }^{16}$ Kanoniczny wykład takiej heroistyczno-cezarystycznej wizji historii i polityki to oczywiście rozprawa: T.Carlyle, Bohaterowie. Cześć dla bohaterówi ipierwiastek bohaterstwa w historii, Kraków 2006.

${ }^{17} \mathrm{Na}$ temat różnicy między personifikacją (jako czynnością poznawczą lub mitologizacją) a personalizacją (jako mechanizmem praktycznego podporządkowania działania ruchów społecznych i instytucji wpływom i cechom osobowości przywódców, osobowym ucieleśnieniom całości) zob. M. Karwat, Personifikacja a personalizacja polityki; «Zeszyty Naukowe» ALMAMER Szkoła Wyższa 2011, nr 2 (64), s. 7-18.

18 Zob. charakterystykę tego fenomenu: L. Jaśkiewicz, Nowożytne samowładztwo rosyjskie i jego interpretacje, «Przegląd Historyczny» 1979, z. 4.
} 
ze swej strony nie słucha i nie musi słuchać nikogo ${ }^{19}$. Mitologicznopropagandowe schematy Demiurga odpowiedzialnego wyłącznie ,przed Bogiem i Historią” jedynie w części (gdy chodzi o sparaliżowanie mechanizmów kontroli społecznej, zapobiegania nadużyciom władzy) odpowiadają rzeczywistości. Przede wszystkim jednak należy zachować świadomość, iż taka - równie sugestywna jak myląca - hipertrofia znaczenia jednostki jest przejawem i rezultatem zapotrzebowania systemowego, a nie po prostu czy wyłącznie jednostkowych ambicji i makiawelicznych uzdolnień.

\section{Totalizacja władzy}

Trzeba wreszcie pamiętać, że monopolizacja władzy posunięta do skrajności (bezwyjątkowa wyłączność, niepodzielność, niezbywalność i samowładność władzy) oparta jest nie tylko na kumulacji władzy w organach państwa jako organach właśnie władczych (w takim czy innym sensie), ale ponadto na opanowywaniu i ,wchłanianiu” we własną infrastrukturę jedynowładztwa (monokratyzmu) instytucji publicznych zapewniających „rząd dusz”, hegemonię ideologiczną (w znaczeniu jak u Gramsciego) - a więc szkół przekształconych w narzędzia indoktrynacji i dyscyplinowania, stowarzyszeń, nawet kościołów ${ }^{20}$ i oczywiście mediów - tak, aby „czwarta władza” też była „nasza” i tylko nasza.

W takim przypadku mamy do czynienia z czymś więcej niż z monopolizacją, bo wręcz z totalizacją władzy. Władza ,totalna” jest wszechobecna, „wszędobylska”, wszechogarniająca. Integralnie, spójnie i kompletnie obejmuje wszystkie dziedziny życia swych obywateli. Ze sfery publicznej wkracza w sferę prywatności i intymności. Zakres jej oddziaływań regulacyjno-sterowniczych, mających wszystkie znamiona ambitnej inżynierii społecznej21 jest taki, iż zdecydowanie przekracza ona funkcje „władzy dyscyplinarnej” (gdzie dyscyplinowanie opiera się tyleż na nakazach, zakazach, sankcjach, represjach, egzekucjach wyma-

${ }^{19}$ Zwraca na to uwagę Czesław Znamierowski. Zob. C. Znamierowski, Szkoła prawa. Rozważania o państwie, Warszawa 1988; fragmenty pt. Moc władcza zbiorowa; Rodzaje jedynowładztwa; Fałszywe założenia jedynowładztwa.

${ }^{20}$ Przykład: „upaństwowienie” Cerkwi w praktyce politycznej caratu; zob. B.A. Uspienski, W.M. Żywow, Car i bóg. Semiotyczne aspekty sakralizacji monarchy w Rosji, Warszawa 1992.

${ }^{21}$ Por. M. Karwat, Inżynieria społeczna. Interpretacja pojęcia, [w:] B. Szatur-Jaworska(red.), Polityki publiczne. Wybrane zagadnienia teoretyczne i metodologiczne, Warszawa 2018. 
gań, co i na „warunkowaniu”, uzależnianiu dostępu do elementarnych nawet dóbr od posłuszeństwa, uległości, gorliwości ${ }^{22}$ ) - przerastając w biowładzę, a więc władzę nad warunkami egzystencji, a nawet nad samym prawem do istnienia określonych populacji ${ }^{23}$. Wyłączna możliwość arbitralnego decydowania o życiu, przeżyciu każdegozobywatelina wszelkich możliwych płaszczyznach (ekonomicznej-źródeł utrzymania, medycznej, edukacyjnej - kiedy proces kształcenia i sam w sobie dostęp lub brak dostępu do edukacji staje się czynnikiem ,selekcji” grup etnicznych, wyznaniowych i in.) to już wręcz monstrualny wymiar monopolu władzy.

\section{„Monokracja”}

W swym podręczniku Mariusz Gulczyński użył terminu monokracja24; niejako przez analogię do żargonowych określeń w rodzaju „monokultura” czy - w języku publicystyki politycznej - „monopartia”.

Co kryje się za tym celnym i pojemnym skrótem myślowym?

Przez monokrację należy rozumieć sytuację, gdy:

1. Wyłączność władzy jest roszczeniem urzeczywistnionym i zagwarantowanym sobie przez siłę rządzącą w praktyce. Wtedy podmiot, który władzę (będącą przecież funkcją społeczną) ${ }^{25}$ zawłaszczył, przypisuje sobie i praktycznie zapewnia wyłączne uprawnienie do rządzenia oraz faktycznie wyłączną możliwość sprawowania władzy, co za tym idzie - do decydowania o wszystkim, co sam uzna za wymagające regulacji, uporządkowania, usankcjonowania lub unieważnienia (to władza określa swoją „materię”).

2. Siła rządząca sama dowolnie (co najwyżej na miarę układu sił, skali przeszkód obiektywnych i oporu przeciwników lub oporu społecz-

22 Jak podkreśla P. Winczorek, dystrybucyjne i redystrybucyjne prerogatywy są nawet ważniejszym i skuteczniejszym środkiem sprawowania władzy niż klasyczne narzędzia przymusu. Zob. P.Winczorek, Nauka o państwie, Warszawa 2011, s. 39, 42.

${ }^{23}$ Jakościowa różnica między władzą dyscyplinarną a biowładzą ukazana została w dziele: M. Foucault, Trzeba bronić społeczeństwa. Wykłady w Collège de France, 1976, Warszawa 1998.

${ }^{24}$ M. Gulczyński, Panorama systemów politycznych świata, Warszawa 2004; część trzecia Współczesne monokracje.

25 Ujęcie władzy (rządzenia, jak i zarządzania) w kategoriach funkcji systemowej, a nie w kategoriach relacji czy tym bardziej ,,władczego statusu” określonych podmiotów rozwinięte jest w pracach: Ch. Barnard, Funkcje kierownicze, Kraków 1997; B. Kaczmarek, Organizacje. Polityka, władza, struktury, Warszawa 2001. 
nego) określa zakres i granice swojej władzy, tzn. nie tylko formalny zakres lub granice uprawnień, ale również zakres swoich obowiązków (jakie problemy społeczne zobowiązana jest rozwiązać). A w sprawie granic swej władzy i odpowiedzialności funkcjonuje na zasadzie „sędzia we własnej sprawie".

3. Ta,,samowładnośćc" (sami siebie ustanawiamy, sami sobie określamy, na co mamy ochotę i co nam wolno; demontując bariery prawne i zwyczajowe, mechanizmy kontroli zewnętrznej) łatwo i szybko przerasta w samowolę, w woluntaryzm rządzących.

4. Władzy tak ,samowładnie” sprawowanej siła rządząca nie zamierza oddać, przekazać komukolwiek innemu. Nie uznaje ona zasady tymczasowości czy przejściowości władzy, równoprawności pretendentów. Jeśli nawet nie likwiduje formalnie i jawnie procedur wyborów, referendów, plebiscytów czy choćby konsultacji społecznych, to skutecznie steruje nimi w taki sposób, aby wynik był zgodny z jej wolą $\mathrm{i}$ interesem.

5. W jeszcze większym stopniu niż „każda władza” monokracja pochłonięta jest utrwalaniem swego panowania, reprodukcją swej władzy i jej wyłączności.

6. Temu zadaniu (które staje się celem samym w sobie) siła rządząca podporządkowuje wszystkie inne. Toteż kryterium selekcji - pozytywnej lub negatywnej - problemów społecznych i własnych zadań oraz ich hierarchizacji (co jest ważne, co jest priorytetem, co można zlekceważyć lub odłożyć ad Kalendas graecas) jest proste: co umacnia i utrwala naszą władzę, co jej zagraża i ją podważa, co nie ma znaczenia ze względu na brak związku z ciągłością i wyłącznością naszej władzy. Jest to szczególna instrumentalizacja ,materii rządzenia i zarządzania": w działalności rządzących wszystkojest podporządkowane samoobsłudze, a społeczna służebność władzy staje się pozorem i pretekstem do manewrów utrwalających rządy i zmierzających do zwalczania, nawet eliminacji przeciwników.

Niewypowiedziane credo polityków praktykujących monokrację sprowadza się do trzech zasad przewodnich:

- Nikt inny nie ma prawa rządzić, tylko JA/MY; władza jest dosłownie MOJA/NASZA (jestem jej nie depozytariuszem, lecz właścicielem);

- Nikt nie może mnie/nas zastąpić; władzy raz zdobytej nie oddam(y) - a w każdym razie czynimy wszystko, bez względu na koszty społeczne, by do utraty własnej władzy nie dopuścić;

- Jeśli już zajdzie taka potrzeba/konieczność, by kogoś innego dopuścić do udziału w mojej/naszej władzy, to może on mieć jedynie status 
wasala, przystawki, ozdobnika (marionetka, figurant ${ }^{26}$; co najwyżej żyrant).

Rozpatrując zaś „monokrację” przez pryzmat atrybutów ontologicznych, przyjmiemy - w podsumowaniu - że ten typ władzy konstytuują i wyróżniają takie cechy jak: wspomniana już samowładność, swoista samowystarczalność, samoreprodukcja i mniej lub bardziej precyzyjnie rozumiana, „wszechwładność”, tzn. zdolność do podporządkowania swoim celom i roszczeniom do sterowania wszelkich możliwych sfer i form życia społecznego, aż po sferę prywatności i intymności w życiu jednostek.

\section{Skrajnie monocentryczny model społeczeństwa i państwa}

Takkompleksowo zaprogramowanai urzeczywistniana ,monokracja” wykracza poza zakres monopolu władzy politycznej-jako wyłączności w sferze politycznej właśnie (w procesach i procedurach rządzenia państwem), lecz oznacza coś więcej: splot władzy i własności27, organiczne zespolenie władzy ,czysto politycznej” (rządzenia) z władzą ekonomiczną 28 i z ideologiczną (niepodzielny „,rząd dusz”). W tym przypadku monopol władzy jest czymś więcej-monopolem integralnego panowania.

W zrozumieniu tej jakościowej transgresji pomocne jest modelowe rozróżnienie Stanisława Ossowskiego (w rozprawie O osobliwościach nauk społecznych) - między porządkiem monocentrycznym, opartym m.in. na tendencjach do unifikacji struktur instytucjonalnych w zgodnościz unifikacją wzorców ideologicznych, a ładem policentrycznym ${ }^{29}$, który skorelowany jest z pluralizmem ideologicznym, kulturowym, politycznym ${ }^{30}$.

Skrajnie monocentryczny model społeczeństwa i państwa opiera się na takiej zasadzie organizacji życia społecznego, iż nie tylko funkcje kierownicze, struktury zarządzania, ale i elementarne więzi społeczne są

26 Analizę mechanizmu figuranctwa i katalog form tego zjawiska znajdzie czytelnik w pracy: M. Karwat, Figuranctwo jako paradoks uczestnictwa. Eseje przewrotne, Warszawa 2004. Por. też bardzo obrazową ,galerię historyczną”: R. Miedwiediew, Ludzie Stalina, Warszawa 1989.

${ }^{27}$ Por. B. Kaczmarek, Polityka - problem władzy, czy problem własności. Własność jako przesłanka władzy, [w:] B. Kaczmarek (red.), Metafory polityki (2), Warszawa 2003.

28 Por. St. Ossowski, O strukturze społecznej, Warszawa 1982; fragment pt. Władza polityczna i władza ekonomiczna.

29 St. Ossowski, Dzieła, t. IV - O nauce, Warszawa 1967; fragment pt. Koncepcje ładu społecznego i typy przewidywań.

${ }^{30}$ Splot tych czynników ukazany jest przejrzyście w rozprawie: F. Gross, Tolerancja i pluralizm, Warszawa 1992. 
skoncentrowane wokół jednego ośrodka władczego, regulującego formy funkcjonowania różnych sfer życia społecznego i narzucającego obowiązujące w nich wartości, wzorce i normy. Ten ośrodek władczy łączy w sobie funkcje zarządcy, strażnika porządku, rozdzielcy i rozdawcy (lecz i konfiskatora) dóbr, nauczyciela, wychowawcy, trenera-tresera. Władza-monolit ma być autorytetem we wszelkich dziedzinach i sprawach (koniec $\mathrm{z}$ autonomią i separacją autorytetów w różnych sferach, gdy kto inny może być autorytetem moralnym, religijnym, jeszcze kto inny artystycznym i zupełnie kto inny - politycznym).

Przejawia się to - koherentnie - w wielu aspektach:

1) ośrodek kierowniczy (np. formalny organ dyktatury, teokratyczne gremia zarządzające państwem, partia komunistyczna opierająca swą rolę „przewodnią i kierowniczą” na schemacie kurateli) sprawuje władzę wyłączną i niepodzielną, a przynajmniej dominuje w życiu politycznym i ideologicznym społeczeństwa jako siła wyznaczająca priorytety i nieprzekraczalne ramy - gwarancje trwałości ustanowionego porządku;

2) niepodzielność tej władzy opiera się na doktrynie i praktyce jednolitości władzy państwowej (choćby nie nazwanej tak wprost), a więc na odrzuceniu, przekreśleniu trójpodziału władz (tym bardziej modelu wzajemnej kontroli, wzajemnego ograniczania się i równoważenia władz, z założeniem, że władza administracyjna na poziomie centralnym i władza lokalna może być sprawowana przez inne siły polityczne, a władza sądownicza pozostaje niezależna od „kluczy” i nacisków partyjno-politycznych) i na przekształceniu względnej separacji trzech rodzajów władz (plus także „czwartej władzy” mediów) w jeden wspólny ,ciąg technologiczny” podporządkowany woli Głównego i Ostatecznego Dyspozytora;

3) ośrodek kierowniczy dąży do całościowego zaprogramowania i ukierunkowania rozwoju społeczeństwa, ma więc ambicje totalnej inżynierii społecznej. Reguluje funkcjonowanie wszystkich sfer, włącznie z życiem powszednim i osobistym jednostek - pod kątem obowiązujących wartości i zasad ideologicznych, nad których wpajaniem, przestrzeganiem i egzekwowaniem czuwa;

4) ośrodek kierowniczy łączy władzę w kilku zasadniczych dziedzinach (ekonomika, polityka, ideologia) nie tylko na zasadzie harmonizacji celów ideologicznych, politycznych i ekonomicznych w strategii rządzenia i w procesach decyzyjnych, ale również w polityce kadrowopersonalnej, poprzez praktykę kumulacji i interferencji ról, stanowisk (w strukturach administracyjnych, parlamentarnych, menadżerskich 
i własnościowych w gospodarce). Integralna kontrola nad całokształtem życia społecznego jest tu sprzężona z symbiozą władzy, własności, korzyści i przywilejów oraz prestiżu i wręcz autorytetu w statusie funkcjonariuszy reżymu politycznego;

5) oficjalnie obowiązuje lub w każdym razie w praktyce przeważa paternalistyczny czy - ściślej mówiąc - paternalistyczno-klientelistyczny wzorzec stosunków między rządzącymi i kierującymi a podporządkowanymi im, uzależnionymi od nich jednostkami, grupami, społecznościami ${ }^{31}$;

6) organizacja życia społecznego jako całości, współzależności między odrębnymi dziedzinami oraz więzi wewnętrzne w poszczególnych środowiskach społecznych są wzorowane i oparte na hierarchiczno-biurokratycznych zasadach działania instytucji (administracji, wojska); może to nawet przerastać w paramilitarny wzorzec funkcjonowania. Oceny, kryteria ocen i hierarchie wartości dzieł i osób, kreowanie lub przekreślanie autorytetu w poszczególnych sferach (w literaturze, sztuce, nauce, ekonomice) są kształtowane lub narzucane metodami biurokratycznymi i dostosowane do preferencji ideologiczno-politycznych siły rządzącej (narzucającej i egzekwującej - także środkami dyscyplinarnymi, represyjnymi - wzorce poprawności, prawomyślności, a nawet naukowości);

7) za gwarancję słuszności i skuteczności kierowaniauznaje się społeczną (np. klasową, rasową, wyznaniową) i ideologiczną jednorodność, a nawet jednolitość układu władzy; której jednak - po stronie zwykłych obywateli i ich zrzeszeń (pozbawianych autonomii, poddanych kontroli i mechanizmom ,transmisji”) ma odpowiadać postępująca uniformizacja ideologiczna i taki imperatyw ,postawy obywatelskiej”, że poparcie lub co najmniej posłuszeństwo wobec rządzących ma być równoznaczne z lojalnością wobec państwa, patriotyzmem itp.;

8) logika systemu prawnego i bieżące funkcjonowanie instytucji prawnych są podporządkowane nienaruszalnym założeniomideologicznymoraz bieżącym dyrektywom politycznym i zapotrzebowaniom propagandowym ze strony centralnego ośrodka władzy. Brakuje realnych - niezależnych od organów władzy i sił rządzących, od zmiennej koniunktury politycznej-gwarancji praw i interesów różnych grup i kategorii społecznych oraz obywateli. W procesach kierowania nieodłącznym

31 Zob. na ten temat: J. Tarkowski, Socjologia świata polityki, t. II - Patroni i klienci, Warszawa 1994; M. Karwat, Paternalistyczny wzorzec polityki. Charakterystyka modelowa, [w:] J. Dzwończyk (red.), Polityka i gospodarka. Teoria i praktyka, Kraków 2019. 
(lub wręcz dominującym) składnikiem jest kształtowanie (ujednolicanie) postaw zgodnych z obowiązującym porządkiem, nakłanianie do afirmacji ustroju i władzy. Toteż przejawy niezadowolenia, oporu społecznego-zwłaszcza w formie czynnej i jawnej-kwalifikowane są i zwalczane jako wykroczenia przeciwko porządkowi, bezpieczeństwu publicznemu lub wręcz jako czyny przestępcze.

Właśnie takie ma oblicze ,monokracja” skrajna - ucieleśniona w nowożytnych reżymach autorytarnych i tym bardziej totalitarnych; znacznie dalej posunięta, pełniejsza, bogatsza niż klasyczne tyranie, despocje czy pragmatycznie praktykowane jedynowładztwo z dawnych epok.

\section{Zakończenie}

Powyższa systematyzacja trzech wymiarów i komponentów ,zawłaszczania władzy" ma to ograniczenie, iż odnosi się do stosunku władzy na poziomie rządzenia lub zarządzania, w formalnych i zhierarchizowanych strukturach administracyjnych lub w relacji między organami państwa a innymi instytucjami publicznymi, zrzeszeniami i obywatelami, do modelu kierowania partią, kościołem lub ruchem społecznym. Na osobne - i zapewne znacznie głębsze - potraktowanie zasługują inne kwestie, częściowo zaliczane do „ukrytych” struktur wpływu - mianowicie: współzależność między koncentracją, kumulacją i monopolizacją lub, przeciwnie, rozproszeniemi dywersyfikacją władzy państwowej a mechanizmami panowania klas, nierządzących bezpośrednio elit władzy, ośrodków lobbingu, teokratycznych kręgów duchowieństwa.

\section{Bibliografia}

C. Barnard, Funkcje kierownicze, Kraków 1997.

T.Carlyle, Bohaterowie. Cześć dla bohaterów i pierwiastek bohaterstwa w historii, Kraków 2006. M. Foucault, Trzeba bronić społeczeństwa. Wykłady w Collège de France, 1976, Warszawa 1998.

J. van Ginneken, The Psychology of Power. Tempations at the Top, New York 2015.

F. Gross, Tolerancja i pluralizm, Warszawa 1992.

M. Gulczyński, Panorama systemów politycznych świata, Warszawa 2004.

A. Hertz, Szkice o totalitaryzmie, Warszawa1995.

J. Hubert, Społeczeństwo synergetyczne, Kraków 2000.

D. Janicka, Ustrój administracji w nowożytnej Europie, Torun 2002.

L. Jaśkiewicz, Nowożytne samowładztwo rosyjskie i jego interpretacje, «Przegląd Historyczny» 1979, z. 4.

B. Kaczmarek, Organizacje. Polityka, władza, struktury, Warszawa 2001. 
B. Kaczmarek, Polityka - problem władzy, czy problem własności. Własność jako przesłanka władzy, [w:] B. Kaczmarek (red.), Metafory polityki (2), Warszawa 2003.

M. Karwat, Figuranctwo jako paradoks uczestnictwa. Eseje przewrotne, Warszawa 2004.

M. Karwat, Inżynieria społeczna. Interpretacja pojęcia, [w:] B. Szatur-Jaworska (red.), Polityki publiczne. Wybrane zagadnienia teoretyczne i metodologiczne, Warszawa 2018.

M. Karwat, Paternalistyczny wzorzec polityki. Charakterystyka modelowa, [w:] J. Dzwończyk (red.), Polityka i gospodarka. Teoria i praktyka, Kraków 2019.

M. Karwat, Personifikacja a personalizacja polityki; «Zeszyty Naukowe» ALMAMER Szkoła Wyższa 2011, nr 2 (64).

M. Karwat, Podmiotowość polityczna. Humanistyczna interpretacja politykiw marksizmie, Warszawa 1980.

L. Kolarska-Bobińska, Centralizacja i decentralizacja. Decyzje, władza, mity, Wrocław 1984.

R. Miedwiediew, Ludzie Stalina, Warszawa 1989.

B. Malinowski, Kultura i jej przemiany, Warszawa 2000.

S. Ossowski, Dzieła, t. IV - O nauce, Warszawa 1967.

S. Ossowski St. Ossowski, O strukturze społecznej, Warszawa 1982.

A. Rothert, Emergencja rządzenia sieciowego, Warszawa 2008.

A. Rothert, Wielopoziomowość władzy sieci, «Studia Politologiczne» 2011, vol. 20.

G. Simmel, Socjologia, Warszawa 1975.

A.G. Spirkin, Zarys filozofii marksistowskiej, Warszawa 1969.

J. Szmatka, Jednostka i społeczeństwo. O zależności zjawisk indywidualnych od społecznych, Warszawa 1980.

J. Tarkowski, Socjologia świata polityki, t. II - Patroni i klienci, Warszawa 1994.

J. Topolski, Metodologia historii, Warszawa 1973.

B.A. Uspienski, W.M.Żywow, Caribóg. Semiotyczne aspekty sakralizacji monarchy w Rosji, Warszawa 1992.

P. Winczorek, Nauka o państwie, Warszawa 2011.

C. Znamierowski, Szkoła prawa. Rozważania o państwie, Warszawa 1988.

C. Znamierowski, Wina i odpowiedzialność, Warszawa 1957. 